\title{
RADIKALISME AGAMA DI INDONESIA (Ditinjau dari Sudut Pandang Sosiologi Kewarganegaraan)
}

\author{
Galih Puji Mulyoto ${ }^{1}$, Galih Puji Mulyono,2 \\ STKIP PGRI Ngawi ${ }^{1}$, Universitas Merdeka Malang ${ }^{2}$ \\ Email:newiota22@gmail.com ${ }^{1}$; galihpujimulyono@gmail.com ${ }^{2}$
}

Naskah diterima: 28/04/2017 revisi: 28/04/2017 disetujui: 28/04/2017

\begin{abstract}
Abstrak
Tujuan penelitian ini adalah untuk mengetahui perkembangan serta faktor penyebab munculnya radikalisme di Indonesia ditinjau dari sudut pandang sosiologi kewarganegaraan dan cara mengatasi munculnya radikalisme dalam masyarakat. Jenis penelitian ini adalah deksriktif kualitatif, dengan menggunakan metode analisis isi.. Subjek dalam penelitian ini adalah isi berita pada media massa, media online maupun buku. Objek dalam penelitian ini adalah mengenai Radikalisme di Indonesia. Teknik pengumpulan data dalam penelitian ini adalah dokumentasi. Sedangkan analisis data adalah dengan mengorganisasikanm data dan pengelolaan data tersebut. Langkah terakhir adalah menarik kesimpulan berdasarkan olah data tersebut. Hasil Penelitian ini adalah awal munculnya gerakan radikalisme di Indonesia karena persoalan kesenjangan-kesenjangan yang masuk ke ranah sosial, ekonomi, bahkan politik. Sebuah bukti bahwa radikalisme ini muncul karena kegagalan negara Indonesia memberikan keadilan sosial serta kesejahteraan seperti yang tertuang dalam pembukaan UUD Negara Republik Indonesia 1945. Negara Indonesia belum mampu mewujudkan kesejahteraan yang mengakibatkan munculnya kesenjangan-kesenjangan sosial. Oleh Karena itu, perlu perbaikkan kesejahteraan masyarakat sehingga radikalisme agama mampu di cegah sedini mungkin.
\end{abstract}

Kata Kunci : radikalisme agama; sosiologi kewarganegaraan

\section{RADICALISM OF RELIGION IN INDONESIA (Viewed from the Sociology Perspective of Citizenship) Abstract}

The purpose of this study is to determine the development and factors causing the emergence of radicalism in Indonesia from the perspective of sociological citizenship and how to overcome the emergence of radicalism in society. This research type is qualitative deksriktif, by using method of content analysis .. Subjects in this research is news content on mass media, online media and book. The object of this research is about Radicalism in Indonesia. Technique of collecting data in this research is documentation. While data analysis is by organizing data and management of data. The final step is to draw conclusions based on the data. The result of this research is the beginning of radicalism movement in Indonesia because of the problem of gaps that enter the social, economic, and even political sphere. A proof that this radicalism arose because of the failure of the Indonesian state to provide social justice and welfare as stated in the opening of the 1945 Constitution. The Indonesian state has not been able to realize the welfare that resulted in the emergence of social inequalities. Therefore, it is necessary to improve the welfare of society so that religious radicalism can be prevented as early as possible.

Keywords: religious radicalism; the sociology of citizenship 


\section{PENDAHULUAN}

Permasalahan yang serius bagi kewarganegaraan di Indonesia sekarang ini, salah satunya adalah menyebarnya radikalisme agama di masyarakat. Survei yang dilakukan oleh Lazuardi Birru dan Lembaga Survei Indonesia tahun 2011, menjelaskan, indeks radikalisme terhadap 33 provinsi di Indonesia. Ada 3 daerah yang paling rentan atau rawan tindakan radikalisme yakni Aceh dengan indeks kerentanan 56,8\%, Jawa Barat $(46,6 \%)$, dan Banten $(46,6 \%)$ (http://www.suarapembaruan.com/home/sur vei-ri-masih-rawan-aksi-radikalisme-danterorisme/12056). Lebih lanjut survei yang dilakukan oleh LIPI pada tahun 2011 di lima universitas di Indonesia UGM, UI, IPB, Unair, Undip menunjukkan peningkatan pemahaman konservatif atau fundamentalisme keagamaan khususnya di kalangan mahasiswa di kampus-kampus.

Sementara itu, Survei Lembaga Kajian Islam dan Perdamaian (LaKIP), yang dipimpin oleh Prof Dr Bambang Pranowo -yang juga guru besar sosiologi Islam di Universitas Islam Negeri (UIN) Jakarta, pada Oktober 2010 hingga Januari 2011, mengungkapkan hampir $50 \%$ pelajar setuju tindakan radikal. Data itu menyebutkan $25 \%$ siswa dan $21 \%$ guru menyatakan Pancasila tidak relevan lagi. Sementara $84,8 \%$ siswa dan $76,2 \%$ guru setuju dengan penerapan Syariat Islam di Indonesia. Jumlah yang menyatakan setuju dengan kekerasan untuk solidaritas agama mencapai $52,3 \%$ siswa dan $14,2 \%$ membenarkan serangan bom (http://www.bbc.com/indonesia/berita_indo nesia/2016/02/160218_indonesia_radikalism e_anak_muda. diakses 22 Februari 2016). Hal ini menunjukkan di beberapa wilayah tersebut rawan konflik serta sudah memasuki berbagai latar belakang usia, pedidikan, daerah dan lain-lain sehingga akan mudah untuk disusupi gerakan-gerakan Islam garis keras seperti ISIS untuk melakukan teror dan kekerasan di masyarakat. Hal ini bukan tanpa alasan karena awal mula munculnya gerakan teroris di awali dengan merebaknya gerakan-gerakan radikal.

Pendapat ini dapat terlihat dari data BNPT (Badan Nasional Penanggulangan Teroris) bahwa sudah 514 WNI yang tergabung ISIS dan 106 di antaranya sudah di deportasi ke Indonesia (http://www.republika.co.id/berita/nasional/ umum/15/11/24/nybej5365-pengawasanjalur-perbatasan-diperkuat-antisipasiterorisme, diakses 29-11-2015). Sementara pada bulan Maret 2015, sebanyak 16 WNI ditangkap otoritas Turki di Gaziantep, kota perbatasan Turki dan Suriah. Mereka ditangkap saat akan menyeberang ke Suriah melalui jalur yang kerap digunakan para pengikut ISIS (Suara Merdeka, edisi 15 Maret 2015). Sedangkan Survei The Pew Research Center pada 2015 lalu, mengungkapkan di Indonesia, sekitar $4 \%$ atau sekitar 10 juta orang warga Indonesia mendukung ISIS - sebagian besar dari mereka merupakan anak-anak muda (http://www.bbc.com/indonesia/berita_indo nesia/2016/02/160218_indonesia_radikalism e_anak_muda. diakses 22 Februari 2016).

Berkembangnya Radikalisme agama tersebut, tentu menimbulkan kekhawatiran di masyarakat akan timbul aksi-aksi teror yang pernah terjadi di Indonesia, seperti teror bom Bali 1 dan 2 serta teror lain. Hal ini didasarkan bahwa radikalisme agama adalah gerakan yang berpandangan kolot dan sering menggunakan kekerasan dalam mengajarkan keyakinan mereka (Nasution, 1995: 124). Sementara secara teoretis, radikalisme identik dengan kekerasan, termasuk penyandingannya dengan kelompok agama tertentu. Walaupun sekadar tataran filosofis dan pemahaman, tentu tidak menjadi masalah karena tidak mengakibatkan kerusakan peradaban manusia. Namun, ketika sudah berubah 
dalam sebuah praksis, biasanya radikalisme ini bermetamorfosis dalam tindakan yang anarkis. Radikalisme yang menghalalkan cara-cara kekerasan dalam memenuhi keinginan atau kepentingan mereka.

Menurut Tinka Veldhuis dan Jorgen Staun dalam Islamist Radicalisation: a Root Cause Model (2009) dalam Muh. Khamdan (2015: 189) menguraikan bahwa akar penyebab dari radikalisme dibedakan menjadi dua faktor, yaitu pada level makro dan level mikro. Level makro adalah kondisi umum yang menjadi prasyarat terbangunnya radikalisme seperti kondisi aktual terkait bidang politik, ekonomi, dan budaya. Rasa ketidakadilan, kesenjang sosial-ekonomi, sehingga memunculkan anggapan negara telah gagal dalam memberikan kesejahteraan dan perlu untuk dilakukan perubahan atau pergantian. Adapun pada level mikro adalah kondisi yang menjadi faktor langsung terjadinya radikalisme pada diri seseorang atau kelompok tertentu sehingga dalam level mikro dibedakan sebagai faktor individual dan faktor sosial. Hal ini mengarah bagaimana munculnya gerakan radikalisme karena dorongan dari diri sendiri maupun kelompok.

Jenis radikalisme ada tiga bentuk, yaitu radikalisme kultural, radikalisme struktural, dan radikalisme langsung. Radikalisme kultural merupakan radikalisme yang melegitimasikan terjadinya radikalisme struktural dan radikalisme langsung. Radikalisme langsung (violence-as-action) sendiri dimaknai sebagai radikalisme yang terlihat secara langsung dalam bentuk kejadian-kejadian atau perbuatan, sehingga mudah dilakukan identifikasi terhadap jenis radikalisme ini, sedangkan radikalisme struktural (violenceas-structure) diartikan sebagai radikalisme yang berbentuk eksploitasi sistematis disertai mekanisme yang menghalangi terbentuknya kesadaran, serta menghambat kehadiran lembaga-lembaga yang dapat menentang eksploitasi dan penindasan. Pada akhirnya dapat ditegaskan bahwa radikalisme dapat dilakukan oleh siapa saja dan dalam kondisi apapun, apakah negara, masyarakat, kelompok tertentu, atau bahkan individu dapat menjadi pelaku radikalisme (M. Sidi Ritaudin, 2014: 398).

Ketika orang berbicara masalah radikalisme, maka pertama yang tergambarkan adalah persoalan tersebut masuk dalam domain politik, yaitu bagaimana sesungguhnya radikalisme yang terjadi merupakan bentuk radikalisme negara yang dilakukan oleh perangkat kekuasaan yang ada terhadap warga negaranya, atau tindak radikalisme yang dilakukan oleh suatu negara terhadap negara lain yang dinilai memiliki sistem dan kepentingan politik yang berbeda, atau setidaknya unsur politik diterjemahkan sebagai adanya pihak lain yang campur tangan dalam fenomena radikalisme yang terjadi. Pemahaman ini kiranya tidaklah berlebihan, dan tidak salah, sebab memang dalam realitas empiriknya memperlihatkan kondisi yang tidak jauh berbeda dari pendapat atau asumsi tersebut (M. Sidi Ritaudin, 2014: 394). Sehingga dapat digaris bawahi bahwa radikalisme merupakan gerakan yang dilakukan oleh individu atau kelompok yang dirugikan oleh fenomena sosio-politik dan sosio-historis.

Melihat fakta di atas, menarik untuk melakukan kajian tentang radikalisme agama di Indonesia. Sementara permasalahan ini, ditinjau dari kajian sosiologi kewarganegaraan untuk mengetahui serta memberikan gagasan mengatasi berbagai permasalahan akibat munculnya radikalisme agama di Indonesia.

\section{METODE}

\section{Jenis Penelitian}

Jenis penelitian yang digunakan termasuk ke dalam jenis penelitian deksriktif kualitatif, yaitu dengan menggunakan metode analisis isi. Sebelum melakukan penelitian, dilakukan pembatasan melalui kategorisasi yang dipilih secara jelas dan menghindari 
perbedaan pandangan dengan peneliti lain. Penelitian ini menggunakan metode analisis isi untuk mendapatkan makna yang terdapat dalam isi berita pada media massa, media online maupun buku mengenai radikalisme di Indonesia.

\section{Waktu dan Tempat Penelitian}

Waktu Penelitian ini dilakukan kurang lebih selama empat bulan yaitu mulai bulan November 2015 sampai dengan bulan Februari 2016.

\section{Subjek Penelitian}

Subjek dalam penelitian ini adalah isi berita pada media massa, media online maupun buku. Objek dalam penelitian ini adalah mengenai radikalisme di Indonesia.

\section{Prosedur}

Tahap tahap dalam melakukan analisis isi (Bulaeng, 2004: 172) sebagai berikut: merumuskan pertanyaan penelitian atau hipotesis, mendefenisikan populasi yang diteliti, memilih sampel yang sesuai dari populasi, memilih dan menetukan unit analisis, menyusun kategori-kategori isi yang dianalisis, membuat sistem hitungan, melatih para pengkode dan melakukan studi percobaan, mengkode isi menurut defdenisi yang telah ditentukan, menganalsis data yang sudah dikumpulkan, dan menarik kesimpulan-kesimpulan dan mencari indikasi.

\section{Data, Intrumen, dan Teknik Pengumpulan Data}

Teknik pengumpulan data pada penelitian ini adalah dokumentasi. Langkah yang dilakukan adalah mendokumentasikan segala yang diperlukan dalam proses penelitian, mulai pemilihan berita baik dari media masa maupun media online serta dari buku-buku terkait radikalisme di Indonesia. Langkah selanjutnya adalah pemilahan berbagai sumber yang dikumpulkan serta dilanjutkan dengan pengkodean. Langkah terakhhir adalah melakukan analisis serta menarik kesimpulan.

Teknik Analisis Data
Teknik analisis isi dilakukan pertamatama mengorganisasikanm data. Data yang terkumpul banyak sekali dan terdiri dari catatan lapangan dan komentar peneliti, gambar, foto, dokumen, berupa laporan, biografi, artikel, dan sebagainya. Pekerjaan analisis data dalam hal ini ialah mengatur, mengurutkan, mengelompokkan, memberikan kode, dan mengategorikannya. Pengorganisasian dan pengelolaan data tersebut bertujuan menemukan tema dan hipotesis kerja yang akhirnya menjadi kesimpulan dari hasil penelitian.

\section{HASIL DAN PEMBAHASAN}

\section{Munculnya Radikalisme dan Gagalnya Negara Kesejahteraan}

Menurut Afif Muhammad, radikal berasal dari kata radic yang berarti akar, dan radikal adalah (sesuatu) yang bersifat mendasar atau 'hingga ke akar-akarnya'. Predikat ini bisa dikenakan pada pemikiran atau paham tertentu, sehingga muncul istilah 'pemikiran yang radikal' dan bisa pula 'gerakan'. Berdasarkan itu, radikalisme diartikan dengan paham atau aliran keras yang menginginkan perubahan atau pembaruan sosial dan politik dengan cara keras atau drastis dan sikap ekstrem suatu aliran politik (Ninin Prima Damayanti, dkk., 2003: 45).

Pada perkembangannya secara global radikalisme sekarang ini, mengarah kepada agama khususnya agama Islam. Hal ini dikarenakan krisis identitas yang berujung pada reaksi dan resistensi terhadap Barat yang melebarkan kolonialisasi di dunia Muslim dan mulai terpecahnya dunia Muslim ke dalam berbagai negara bangsa (nation-state) (Syamsul Rijal, 2010: 215). Oleh karena itu, muncul gerakan radikalisme yang menggunakan kekerasan untuk mencapai target politik yang ditopang oleh sentimen atau emosi keagamaan.

Pandangan yang lain, Nur Syam (2005: 11) mengemukakan radikalisme secara sosiologis terjadi ketika masyarakat berada dalam situasi kesenjangan antara 
nilai dengan pengalaman-pengalaman sehari-hari. Inti dari radikalisme adalah menghendaki adanya perubahan pergantian terhadap suatu pemerintahan di masyarakat. Dalam setiap aksinya Radikalisme menggunakan kekerasan, dan suka memaksakan kehendak. Tujuan dari radikalisme adalah kekuasaan dan penguasaan politik dengan mengedepankan atau memanfaatkan golongan, kelompokkelompok primordial (suku, bangsa, ras, keyakinan, keagamaan, dan kepercayaan). Berbagai pendekatan primordial inilah gerakan radikalisme membangun kekuatan untuk mendapatkan legitimasi dan solidaritas (Dwilaksana, 2014).

Hal ini sejalan dengan kerangka pemikiran Islam radikal tersebut pada dasarnya adalah sebagai berikut:

a. Islam harus menjadi dasar negara

b. Syariat harus diterima sebagai konstitusi negara.

c. Kedaulatan politik ada di tangan Tuhan

d. Gagasan tentang negara-bangsa (nationstate) bertentangan dengan konsep umat yang tidak mengenal batas-batas politik atau kedaerahan

e. Prinsip syura (musyawarah) berbeda dengan gagasan demokrasi (Khamami Zada, 2002:11).

Pemikiran menarik dari Ahmad Rizky Mardhatillah Umar, (2010: 172) menggambarkan penyebab radikalisme. Pertama, warisan sejarah umat Islam yang konfl iktual dengan rezim, karena ada modus-modus penindasan politik Islam yang terjadi pada beberapa fragmen sejarah, khususnya Orde Baru. Kelompok yang termarjinalkan secara historis tersebut, dengan kesadaran sejarah, mencoba mengembalikan posisi politik Islam dengan jalan-jalan nonnegara dan struktural. Dalam konteks global, adanya marjinalisasi politik Islam oleh hegemoni dalam politik internasional (Amerika Serikat) menyebabkan adanya kesadaran untuk mengembalikan daulat politik Islam. Transnasionalisme membawa kesadaran tersebut ke Indonesia dalam bentuk gerakangerakan politik Islam

Kedua, fenomena ekonomi-politik. Selain adanya penindasan politik, argumen kedua dari artikel ini adalah adanya penindasan ekonomi-politik. Dengan argumen ini, radikalisme muncul karena akses kapitalisme yang menciptakan mereka yang tak memiliki akses pada sumbersumber modal. Dalam bahasa ekonomipolitik, pendekatan ini dikenal dengan "pendekatan kelas". Artinya, respons radikalisme pada dasarnya adalah respons kelas untuk melawan hegemoni kapital yang oligarkis dengan negara. Hal ini menganut sepeti teori pertarungan antar kelas

Sementara itu, akar munculnya gerakan radikalisme ini di Indonesia tidak bisa dilepaskan pasca-Orde Baru dari pergantian rezim yang semakin terbuka. Kemunculan gerakan radikalisme agama, seperti Jemaah Islamiyah (JI) maupun yang terang-terangan seperti Laskar Jihad, Laskar Jundulloh, FPI, MMI, HTI, dan lain-lain merupakan dampak ikutan dari semakin terbukanya iklim politik dan demokrasi pasca-tumbangnya Orde Baru. Tanpa kehadiran era Reformasi, hampir dapat dipastikan kelompok-kelompok garis keras tersebut tidak akan berani muncul ke permukaan akibat represi politik yang dilakukan oleh rezim berkuasa. Keterbukaan politik yang diintroduksi oleh Presiden Habibie, penerus Presiden Soeharto, terbukti memberi semangat baru bagi kelompok masyarakat untuk menyuarakan berbagai aspirasi dan kepentingan politiknya secara bebas dan leluasa (Masdar Hilmy, 2015: 408).

Memasuki Era Reformasi, penataan kehidupan agama di ruang publik memang jauh lebih longgar dibanding era Orde Baru. Pada masa Soeharto, Indonesia menerapkan UU anti-subversi yang sering disalahgunakan untuk tujuan-tujuan represif melalui Penetapan Presiden Republik Indonesia No 11 Tahun 1963 tentang Pemberantasan Kegiatan Subversi (Hans 
Thoolen dalam Masdar Hilmy, 2015: 410. Akibatnya, UU ini seringkali dianggap membelenggu kemerdekaan dan kebebasan publik. Seiring dengan tumbangnya Orba dan pergantian rezim ke era Reformasi, UU ini menjadi salah satu yang diaspirasikan untuk dicabut. Presiden BJ. Habibie, sebagai penerus Presiden Soeharto, mengambil inisiatif pencabutan UU tersebut (Nadirsyah Hosen, dalam Masdar Hilmy, 2015: 410). Pencabutan UU tersebut terbukti menjadi pintu masuk bagi kelompok aliran dan keagamaan untuk kembali aktif setelah sekian lama tiarap. Pada saat itulah berbagai ormas radikal bermunculan. Mereka memanfaatkan kebebasan yang diberikan oleh Presiden Habibie sebagai kendaraan untuk memasarkan gagasan-gagasan keagamaannya yang radikal.

Sedangkan menurut Ahmad Rizky (2010: 183-184), penyebab munculnya radikalisme di Indonesia secara garis besar terjadi dikarenakan munculnya kesenjangan sosial dan ekonomi karena adanya kelompok yang menguasai akses pada modal dan kekuasaan sejak era pergerakan nasional. Kelompok Islam politik yang tak terakomodasi dalam struktur politik Indonesia mengambil langkah-langkah yang radikal dan berkarakter militeristik. Sementara secara ekonomi-politik, akar dari Islam Radikal adalah adanya pertentangan antara kelas borjuasi yang berwajah "moderat" dan "pro-pemerintah" melawan mereka yang termarjinalisasi. Hal ini secara nasional dapat kita baca melalui adanya akumulasi kapital di kalangan kelompok pemodal, dan dalam level internasional dapat kita baca melalui skema dependensia antara Indonesia dengan negara-negara yang menjadi hegemoni melalui praktik-praktik ekonomi. Sehingga kesenjangan dan ketimpangan ekonomi memunculkan tindakan radikalisme agama yang menuju ke aksi terorisme.

Pemaparan dari munculnya gerakan radikalisme di Indonesia diikuatkan dengan berbagai fakta, seperti survei yang dirilis
Lingkaran Survei Indonesia (LSI) (19/11/2015) menunjukkan faktor ekonomi dipercaya meningkatkan aksi terorisme. Lebih rinci hasil survei menjelaskan kondisi ekonomi yang sulit akan memicu aksi teror 83,78 persen. Data tersebut juga menunjukkan kondisi ekonomi yang berada pada kelas ekonomi rendah dikhawatirkan meningkatkan potensi terorisme. Seperti kita ketahui, kasus terorisme yang terjadi sebelumnya di Indonesia menunjukkan bahwa latar belakang ekonomi pelaku terorisme adalah mereka yang sulit kehidupan ekonomi. Gerakan radikalisme sering menjadikan kondisi ekonomi masyarakat yang lemah untuk mendoktrin serta mempengaruhi warga untuk bergabung dalam kelompok radikal. Contoh kelompok radikal gerakan ISIS yang mengincar warga negara Indonesia untuk bergabung dengan iming-iming gaji Rp 25 juta-Rp 39 juta sepekan (Suara Merdeka, hal 11, edisi 15 Maret 2015). Oleh karena itu, diperlukan peran negara untuk meningkatkan ekonomi kehidupan warga negaranya serta melindungi warga negaranya dari ancaman. Selain faktor ekonomi, menurut survei LSI di atas, terdapat faktor munculnya radikalisme, yaitu peraturan daerah yang diskriminatif. Dalam survei itu menyebutkan peraturan daerah berpengaruh memicu terorisme: 59,62 persen. Komnas Perempuan mencatat, di tahun 2015 tak kurang dari 300 peraturan daerah mengandung isu diskriminatif.

Sementara dari sudut pandang kajian sosiologi kewarganegaraan munculnya radikalisme adalah gambaran gagalnya negara dalam memberikan kesejahteraan bagi warga negaranya. Secara konsep negara kesejahteraan adalah sebuah model ideal pembangunan yang difokuskan pada peningkatan kesejahteraan melalui pemberian peran yang lebih penting kepada Negara dalam memberikan pelayanan sosial secara universal dan komprehensif kepada warganya. Indonesia sebagai yang menganut negara kesejahteraan menunjukkan indikasi 
belum mampu mewujudkan cita-cita memberikan kesejahteran bagi warga negaranya. Secara sederhana Negara kesejahteraan (welfare state) adalah negara yang menganut sistem ketatanegaraan yang menitik beratkan pada mementingkan kesejahteraan warganegaranya. Tujuan dari negara kesejahteraan bukan untuk menghilangkan perbedaan dalam ekonomi masyarakat, tetapi memperkecil kesenjangan ekonomi dan semaksimal mungkin menghilangkan kemiskinan dalam masyarakat.

Data Statistik pertumbuhan ekonomi nasional dari Badan Pusat Statistik (BPS) menunjukkan bahwa jumlah penduduk miskin di Indonesia pada bulan Maret 2015 mencapai 28,59 juta orang (11,22 persen), bertambah 0,86 juta orang dibandingkan dengan penduduk miskin pada September 2014 yang sebanyak 27,73 juta orang $(10,96$ persen). Selain itu, jumlah pengangguran pada Agustus 2015 mencapai 7,6 juta orang, dengan Tingkat Pengangguran Terbuka (TPT) mengalami peningkatan dari 5,81 persen pada Februari 2015 menjadi 6,18 persen pada Agustus 2015. Sedangkan pada indeks Gini atau tingkat ketimpangan pendapatan dan aspek kemiskinan di Indonesia menunjukkan meningkat $0,44 \%$ dibandingkan tahun 2014. Data diatas menunjukkan Indonesia masih terjadi kesenjangan baik ekonomi maupun sosial di masyarakat.

Persoalan di atas akan menjadi penyebab bagi kemunculan mereka yang menginginkan adanya perubahan politik secara radikal karena menganggap pemerintah tidak mampu memberikan keadilan sosial serta kesejahteraan bagi warga negaranya. Pada akhirnya, hal tersebut dijadikan menjadi alasan untuk membentuk negara Islam. Maeskipun gagasan tersebut hanya sebuah alternatif bagi kelompok radikal, karena model negara yang dianut oleh Indonesia sekarang tidak terbukti mampu membawa kesejahteraan bagi warga negara. Dalam konteks yang lebih luas, dorongan untuk melakukan aksi pengeboman, mengubah bentuk negara, dan lain sebagainya, pada intinya muncul karena dua alasan. Pertama, karena negara tidak mampu memberikan hak-hak bagi mereka yang terjerumus oleh kemiskinan struktural. Kedua, karena sebagian umat Islam di Indonesia secara genealogis memiliki akar perjuangan yang kuat dalam melawan penjajah, dan keberadaan korporasi asing. Contoh munculnya ISIS sebagai organisasi radikal dalam melakukan aksi terorisme. ISIS menghasut serta melakukan propaganda untuk membentuk koalisi menciptakan negara Islam yang memegang syariah Islam, meskiun pada akhirnya justru jauh dari syariah Islam karena membunuh dan melakukan kekerasan pada orang tidak bersalah.

Propaganda ISIS akhir-akhir ini memang sangat mengkhawatirkan. Media sosial, banyak dijadikan ISIS untuk melakukan merekut serta menunjukkan eksistensinya kepada dunia. Selain itu, banyak iming-iming yang ditawarkan dalam perekutan serta propaganda di media online. Hal tersebut tentu akan menimbulkan erosi kewarganegaraan tidak hanya datang sebagai menanggapi konteks global kontemporer tumbuh ketidakamanan, tetapi, berfungsi sebagai katalis untuk ketidakamanan lebih lanjut dari berbagai jenis, yaitu, politik, sosio-ekonomi, pribadi dan sebagainya (Alexandra Dobrowolsky, 2007: 629). Maksudnya Gerakan ISIS ini akan melunturkan semangat nasionalisme serta lunturnya identitas nasional suatu negara dan mengganggu stabilitas keamanan dunia. Dalam hal ini, warga negara yang bergabung dalam gerakan radikal atau ISIS sudah tidak lagi aktif ikut dalam berpartisipasi baik dalam kegiatan pemerintahan, pemilu dan lain-lain. Bahkan meninggalkan status kewarganegaraan yang dimiliki dan bergabung dengan kelompok tersebut.

Gerakan radikalisme sekarang telah merambah pada generasi muda. Hal yang 
perlu ditakutkan adalah berbagai ketimpangan sosial-ekonomi akan memudahkan generasi muda disusupi gerakan radikal. Faktor yang mendasar seperti yang disampaikan Faishal Basri, Ekonom dan Dosen FE Universitas Indonesia, menyatakan bahwa tingginya pengangguran dikalangan usia muda dapat memicu gerakan radikalisme (http://katadata.co.id/opini/2017/01/11/mend eteksi-akar-ekonomi-dari-radikalisme-dangejolak-sosial, diakses 22 Februari 2016). Hal ini berkaca pada kasus di negara-negara timur tengah serta data ketimpangan pendapatan antara orang kaya dan miskin di Indonesia. Salah satu alasannya adalah kalangan muda belum memiliki jati diri yang kuat. Ketika mereka dihadapkan dengan sulitnya mencari lapangan kerja, disisi lain ada beberapa orang yang mencari kekayaan dengan cara yang instan, seperti: korupsi, penipuan dan sebagainya. Sedangkan Survei The Pew Research Center pada 2015 lalu, mengungkapkan di Indonesia, sekitar $4 \%$ atau sekitar 10 juta orang warga Indonesia mendukung ISIS , sebagian besar dari mereka merupakan anak-anak muda (http://www.bbc.com/indonesia/berita_indo nesia/2016/02/160218_indonesia_radikalism e_anak_muda. diakses 22 Februari 2016). Sehingga dapat digaris bawahi bahwa aksi terorisme maupun radikalisme adalah wujud perlawanan kelas yang termarjinalkan oleh oligarki kelas pemilik modal (borjuasi) dan negara. Subordinasi atas kelompok kelas marjinal dalam kasus Indonesia kelas marjinal tersebut adalah gerakan politik Islam menimbulkan kesadaran kelas untuk merebut peran negara yang dianggap gagal dalam mewujudkan kesejahteraan (Ahmad Rizky, 2010: 177).

\section{Gagasan Mengatasi Radikalisme di Indonesia}

Radikalisme agama bukan suatu yang mustahil untuk dihilangkan dari masyarakat, membutuhkan cara untuk pencegahan, penanggulangan maupun merehabilitasi masyarakat yang terjelumus dalam kelompok radikal. Karena bukan tidak mungkin apabila salah dalam memberikan perlakuan justru akan memunculkan rasa dendam dan memunculkan kelompok radikalisme baru. Seperti kita ketahui di Indonesia kelompok radikalisme agama yang telah berubah menjadi aksi teroris, telah banyak melakukan aksi teror serta kekerasan dan tidak sedikit pelaku yang sudah ditangkap. Namun tidak menimbulkan efek jera malah muncul aksi teror lain dengan kelompok yang baru. Sementara itu Polisi telah menangkap hampir 700 orang dalam 10 tahun terakhir, namun hal itu tidak diimbangi perlawanan signifikan dalam konteks membendung paham radikalisme (http://www.bbc.com/indonesia/berita_indo nesia/2012/09/120925_analyst_terror_solo). Oleh karena itu dibutuhkan gagasan yang tepat agar radikalime agama tidak berkembang di Indonesia.

Berdasarkan fakta-fakta yang di atas, sebenarnya sudah pemerintah mencoba memberikan solusi salah satunya melalui progam bantuan sosial serta beberapa pencegahan seperti program pemberdayaan dan perlindungan sosial melalui APBN-P yang lalu. Kemensos menganggarkan dari alokasi anggaran Rp 8,1 triliun pada 2014, disetujui untuk dinaikkan menjadi sebesar Rp 22,4 triliun pada tahun 2015 (Suara Merdeka, edisi 15 Maret 2015, hal. 11). Anggaran sebesar itu tentu sangat bermanfaat jika betul-betul dapat diarahkan bagi pembinaan masyarakat miskin yang berpotensi direkrut oleh ISIS. Selain itu, mencoba mensinergikan lembaga-lembaga untuk mengangani gerakan radikal ini, seperti POLRI, Kejaksaan, BNPT, Kemensos serta lembaga-lembaga agama seperti NU dan Muhammadiyah untuk bersama mengatasi gerakan radikalisme di Indonesia.

Beberapa negara di dunia mempunyai permasalahan yang sama dengan Indonesia terkait kelompok radikal. Seperti Australia 
telah mengeluarkan kebijakan untuk mengatasi berkembangannya gerakan ini, Salah satunya yaitu melalui membuat UU tentang pencabutan kewarganegaraan seseorang yang ikut serta dan menjadi bagian dalam ISIS. Kewarganegaraan sebenarnya adalah status yang diberikan kepada mereka yang penuh anggota komunitas. Semua orang yang memiliki status sama sehubungan dengan hak-hak dan kewajiban yang status. Hal ini penting dalam mengintegrasikan proses kewarganegaraan memerlukan pengertian masyarakat keanggotaan berdasarkan kesetiaan. Namun apabila dalam kenyataannya telah melakukan pelanggaran, maka status kewarganegaraan tersebut akan dihapus. Dengan terhapusnya kewarganegaraan seseorang tentu akan hilang pula hak sosial, hak sipil serta hak politik warga negara tersebut.

Sementara di Indonesia sanksi ini masih dalam tahap wacana, dan akan dikaji ulang tentang keefektifan cara tersebut dalam menanggulangi gerakan ISIS. Hal ini karena masih berbenturan dengan Undangundang nomor 12 Tahun 2006 Pasal 23 huruf a dan e, yang berbunyi, WNI kehilangan kewarganegaraannya jika yang bersangkutan memperoleh kewarganegaraan lain atas kemauannya sendiri atau secara sukarela masuk dalam dinas negara asing (source:

http://international.sindonews.com/read/101 7349/40/sekitar-500-wni-telah-bergabungdengan-isis-1435326221. diakses 29-112015). Apabila bila sanksi ini benar akan berlaku maka Masyarakat yang dinamis akan menurun, dan perkembangan ini adalah dasar nyata dari erosi kewarganegaraan di negara modern yang demokratis. Penurunan ini sebenarnya privatisasi identitas masyarakat mengikuti privatisasi publik (Isin \& Turner, 2007: 11). Artinya, paham radikalisme ISIS akan mempengaruhi tingkat partisipasi serta status kewarganegaraan di Indonesia. Hal tersebut menunjukkan bahwa Masyarakat modern tidak lagi didasari oleh jaringan padat asosiasi, klub, persaudaraan, kapel dan asosiasi komunal, Sehingga terjadi penurunan modal sosial, dalam hal ini sebagai indeks utama dari erosi kewarganegaraan (Putnam 1993 dan 1995).

Mengenai kewarganegaraan modern Jenine Brodie merujuk pada pendapat Held (1999) yang mengatakan bahwa kewarganegaraan modern walaupun masih tetap terkait dengan partisipasi dan pembentukan identitas, tetapi dipahami dalam kerangka hak dan kewajiban yang dimiliki individu sebagai anggota warga negara yaitu sebagai bagian dari komunitas suatu bangsa. Memang dari definisinya, kewarganegaraan modern memiliki pengertian yang terbatas karena kewarganegaraan berkonotasi membatasi keanggotaan dalam wilayah dan negara yang diakui secara internasional namun substansi kewarganegaraan telah berkembang seiring waktu sehingga pendeflnisiannya memuat hubungan antara individu dan negara kaitannya dengan hak. Semtentara apabila dilihat dari teori kewarganegaraan modern marsahall, kegiatan radikalisme pada bentuk terorisme akan mengakibatkan hilangnya yang berujung hak-hak warganegara dimana hak sipil, hak sosial dan hak politik. Oleh karena itu, erosi kewarganegaraan yang disebabkan radikalisme akan mengikis semangat nasionalisme warga negara ke arah apatis terhadap negara, serta berupaya untuk membentuk pemerintahan sesuai dengan tujuan dan organisasi mereka.

Negara Denmark memulai memilih "pendekatan lunak" dengan merangkul kembali "jihadis-jihadis" yang kembali dari Suriah. Mereka menggunakan Dialog sebagai medium terbaik untuk mengubah cara pandang seseorang agar bisa kembali membaur kepada masyarakat. Alasannya adalah dengan bantuan-bantuan semacam ini, mereka tidak melakukan kejahatan setelah kembali dari Suriah. Ternyata usaha tersebut membawa dampak yang positif, 
Citizenship Jurnal Pendidikan Pancasila dan Kewarganegaraan Vol 5 No 1 April 2017, hal 64-74 Avaliable online at : http://e-journal.unipma.ac.id/index.php/citizenship

p-ISSN: 2302-433Xp e-ISSN 2579-5740

terlihat pada tahun 2013 tak kurang dari 30 warga pergi ke Suriah, pada akhir 2014 hanya satu orang yang pergi ke sana. Jadi, pendekatan lunak dan dialog persuasif dengan komunitas Muslim membawa hasil (http://www.bbc.com/indonesia/dunia/2015/ 11/151126_dunia_deredakalisasi_denmark). Melihat apa yang dilakukan pemerinah Dermark tentu bisa diterapkan pula di Indonesia. Karena selama ini memang penanganan orang-orang pelaku terorisme maupun kelompok radikal masih cenderung dengan pendekatan militeristik.

\section{SIMPULAN DAN SARAN}

\section{Simpulan}

Persoalan radikalisme adalah persoalan kesenjangan-kesenjangan yang masuk ke ranah sosial, ekonomi, bahkan politik. Sebuah bukti bahwa radikalisme ini muncul karena kegagalan negara Indonesia memberikan keadilan sosial serta kesejahteraan seperti yang tertuang dalam pembukaan UUD Negara Republik Indonesia 1945. Negara Indonesia belum mampu mewujudkan kesejahteraan yang mengakibatkan munculnya kesenjangankesenjangan sosial. Oleh karena itu, perlu perbaikkan kesejahteraan masyarakat sehingga radikalisme agama mampu di cegah sedini mungkin.

\section{Saran}

Berdasarkan hasil temuan maka untuk mencegah tindakan radikalisme pemerintah perlu memlakukan perbaikan kesejahteraan melalui penciptaan lapangan kerja, pemberian modal usaha dan pelatihan kerja serta mengurangi kesenjangan sosialekonomi harapannya mampu mengurangi serta mencegah munculnya gerakan radikalisasi agama. Selain itu melakukan pendekatan-pendekatan yang kooperatif menjauhkan dari kesan diskriminasi dan kekerasan kepada kelompok-kelompok radikal.

\section{DAFTAR PUSTAKA}

Ahmad Rizky Mardhatillah Umar. (2010). Melacak Akar Radikalisme Islam di Indonesia. Jurnal Ilmu Sosial dan Ilmu Politik. Volume 14, Nomor 2, November 2010. hlm. 169-186. ISSN 1410-4946.

Alexandra Dobrowolsky. (2007). (In)Security and Citizenship: Security, Im/migration and Shrinking Citizenship Regimes. Theoretical Inquiries in Law. Vol 8.2 (2007). hlm. 629-661.

Bryan S. Turner (2001). The erosion of citizenship. British Journal of Sosiologi. 2 (52). hlm. 189-209.

Bulaeng, Andi. (2004.) Metode Penelitian Komunikasi Kontemporer. Penerbit Andi. Yogyakarta.

Engin F. Isin \& Bryan S. Turner. (2007). Investigating Citizenship: An Agenda for Citizenship Studies. Citizenship Studies. Vol. 11, No. 1. February 2007. hlm. 5-17.

Hilmy, Masdar.( ) Radikalisme Agama Dan Politik Demokrasi Di Indonesia Pasca-Orde Baru. MIQOT Vol. XXXIX No. 2 Juli-Desember 2015. hal. 407-425.

Khamdan, Muh. (2015). Rethinking Deradikalisasi: Konstruksi Bina Damai Penanganan Terorisme. Addin, Vol. 9, No. 1, Februari 2015. hal. 181-204.

Mohammad Kosim. (2006). Pesantren dan Wacana Radikalisme. Karsa, Vol. IX No. 1 April 2006. hlm. 842-853.

Ninin Prima Damayanti, Imam Thayibi, Listya Adi Gardhiani, Indah Limy. (2003). Radikalisme Agama Sebagai Salah Satu Bentuk Perilaku Menyimpang: Studi Kasus Front Pembela Islam. Jurnal Kriminologi Indonesia Vol. 3 No. I Juni 2003 : 43 -57 . 
Citizenship Jurnal Pendidikan Pancasila dan Kewarganegaraan Vol 5 No 1 April 2017, hal 64-74 Avaliable online at : http://e-journal.unipma.ac.id/index.php/citizenship p-ISSN: 2302-433Xp e-ISSN 2579-5740

Peter Kivisto and Thomas Faist. (2007). Citizenship: Discourse, Theory, and Transnational Prospects. Blackwell Publishing Ltd.

Prof. Dr. Nur Syam, M.Si. (2005). Radikalisme Dan Masadepan Hubungan Agama-Agama: Rekonstruksi Tafsir Sosial Agama 1. Makalah. Dipresentasikan pada tanggal 10 Oktober 2005 Guru Besar IAIN Sunan Ampel dalam Bidang Sosiologi.

Ritaudin, M. Sidi. (2014). Radikalisme Negara Dan Kekuasaan Perspektif Politik Global. Kalam: Jurnal Studi Agama dan Pemikiran Islam. Volume 8, Nomor 2, Desember 2014. hal. 389-414.

Suara Merdeka, hal 11, edisi 15 Maret 2015.

Sun Choirol Ummah. (2012). Akar Radikalisme Islam Di Indonesia. Humanika No. 12/Sept. 2012. hlm. 112-124.

Syamsul Rijal (2010). Radikalisme Islam Klasik dan Kontemporer: Membanding Khawarij dan Hizbut Tahrir. al-fikr, Volume 14 Nomor 2 Tahun 2010. hlm. 214-231.

Umar, Ahmad Rizky Mardhatillah. (2010). Melacak Akar Radikalisme Islam di Indonesia. Jurnal Ilmu Sosial dan
Ilmu Politik. Volume 14, Nomor 2, November 2010. ISSN 1410-4946. hal. 169-186.

Zada, Khamami. (2002). Islam Radikal : Pergulatan Ormas-ormas Islam Garis Keras di Indonesia, Jakarta : Teraju.

\section{Internet:}

http://international.sindonews.com/read/101 7349/40/sekitar-500-wni-telahbergabung-dengan-isis-1435326221. diakses 29-11-2015.

http://www.republika.co.id/berita/nasional/u mum/15/11/24/nybej5365pengawasan-jalur-perbatasandiperkuat-antisipasi-terorisme, diakses 29-11-2015.

http://www.bbc.com/indonesia/dunia/2015/1 1/151126_dunia_deredakalisasi_den mark

http://www.bbc.com/indonesia/berita_indon esia/2012/09/120925 analyst terror solo

http://www.bbc.com/indonesia/berita_indon esia/2016/02/160218_indonesia_radi kalisme anak muda. diakses 22 Februari 2016

http://katadata.co.id/opini/2017/01/11/mend eteksi-akar-ekonomi-dariradikalisme-dan-gejolak-sosial, diakses 22 Februari 2016 